\title{
Risk Factors Related to the Events of Leprosy in Children age 5-14 Years in City of Sorong West Papua
}

\author{
Yehud Maryen $^{1}$, Jansen Parlaungan ${ }^{1}$, Elisabeth Samaran ${ }^{1}$, Mustamir Kamaruddin ${ }^{1}$, Anwar Mallongi ${ }^{2}$ \\ ${ }^{1}$ Lecturers of Poltekkes Kemenkes Sorong, ${ }^{2}$ Professor of Environmental Health Department, \\ Faculty of Public Health, Hasanuddin University, Makassar
}

\begin{abstract}
Leprosy is an infectious disease which is a national public health problem, because several regions in Indonesia have a high prevalence rate. There were 17,012 new cases of leprosy in Indonesia in 2010, consisting of 13,734 cases of Multi Basiler and 3,278 cases of PausiBasiler with a Newly Case Detection Rate (NCDR) of 7.22 per 100,000 population. The number was recorded as many as 20,329 cases with a prevalence of 0.86 per 10,000 population.

In Indonesia, there are 12 provinces that still have leprosy rates above one person per 10,000 population, including the Province of Nangro Aceh Darussalam (1.51), South Kalimantan (1.07), East Java (1.67), North Sulawesi (2.57), Central Sulawesi (1.17), South Sulawesi (2.02), Southeast Sulawesi (1.21), Gorontalo (3.62), NTT (1.17), North Maluku (9.51), Maluku (3.47), and Papua (4.62).

This study aims to see the risk factors for leprosy in children aged 5-14 years in Sorong City, West Papua Province. This type of research is a case control study and the population is children 5-14 years old in Sorong City with a sample of 54 respondents. The research data were analyzed using SPSS 16. Data analysis used the Chi-Square test.

The results showed that the socioeconomic level $\mathrm{p}(0,000)<\operatorname{sig}(0.05)$ and $(\mathrm{OR})=13.600(>1=$ risk risk) history of home contact $\mathrm{p}(0.000)<\mathrm{sig}(0.05)$ and the odd ratio value $(\mathrm{OR})=35,714(>1=$ risk risk) associated with the incidence of leprosy in children aged 5-14 years in Sorong City, while education $\mathrm{p}$ $(0.569)>\operatorname{sig}(0.05)$, parent's occupation $p(0.766)>\operatorname{sig}(0,05)$, personal hygiene $\mathrm{p}(0.136)>\operatorname{sig}(0.05)$ is not a risk factor for the incidence of leprosy in children in Sorong City.

It is recommended that parents increase knowledge about leprosy transmission by seeking information from both health workers and the mass media, as well as the public who can actively participate in supporting government programs and efforts to prevent leprosy.
\end{abstract}

Keywords: Risk Factors, Leprosy in Children, West Papua.

\section{Introduction}

Leprosy or also known as leprosy or Morbus Hansen is an infectious disease caused by Mycobacterium leprae. This disease is still a health problem in some developing countries.

\section{Corresponding Author:}

Yehud Maryen

Lecturers of Poltekkes Kemenkes Sorong

e-mail: yehudmayen@gmail.com
Leprosy is a chronic disease that attacks nerves edges, skin and other body tissues and can cause permanent disability. Leprosy is a chronic disease that attacks nerves edges, skin and other body tissues and can cause permanent disability.

According to the Word Health Organizations (WHO), leprosy is classified into 2, namely: type PB (Pausibacillary) and type MB (multi bacillary) ${ }^{3}$. As of March 2013, there were 189,018 cases recorded, and the number of new cases in 2012 was 232,857 cases. There were 17,012 new cases of leprosy in Indonesia in 2010, 
consisting of 13,734 cases of Multi Basiler and 3,278 cases of PausiBasiler with a Newly Case Detection Rate (NCDR) of 7.22 per 100,000 population. The number of registered cases was 20,329 cases with a prevalence of 0.86 per 10,000 population ${ }^{4}$.

There are 12 provinces in Indonesia that still have leprosy rates above one person per 10,000 population. These provinces are NAD (1.51), South Kalimantan (1.07), East Java (1.67), North Sulawesi (2.57), Central Sulawesi (1.17), South Sulawesi (2.02), Southeast Sulawesi (1.21), Gorontalo (3.62), NTT (1.17), North Maluku (9.51), Maluku (3.47), and Papua (4.62) ${ }^{2}$.

The indicators used in leprosy are the proportion of MB leprosy and the proportion of children with leprosy (less than 14 years) among new sufferers, which shows the main source and level of transmission in the community.

Provinces with the highest proportion of MB leprosy in 2015 were Bengkulu, Central Kalimantan (100\%), Lampung (94.34\%) and Gorontalo (91.03\%). Meanwhile, the proportion of children leprosy in the same period is around $10 \%-12 \%$. Provinces with the highest proportion of leprosy in children are West Papua (30.82), Papua (23.62\%), and North Maluku (19.49\%) ${ }^{6}$.

The proportion of children aged less than 14 years who suffer from leprosy is one of the indicators of the success of the leprosy eradication program, where this figure can be used to see the current state of transmission and estimate the need for medicine. Based on these problems, researchers are interested in knowing the risk factors associated with the incidence of leprosy in children aged ${ }^{5-14}$ years in Sorong City, West Papua Province.

\section{Subjects and Method}

Types of Research: The type of research used is an analytical study with a case control study approach. To determine the estimation of the size of the risk factors for disease incidence, it is determined using the Odds ratio $(\mathrm{OR})$ value.

Research Sites: This research was conducted in the City of Sorong, West Papua in October - November 2017.

Sample: From the study population selected as the sample of this study with the following inclusion and exclusion criteria ${ }^{15,16}$.

\section{Research Results}

1. Overview of the Research Location: Sorong City is an integral part of the province of West Papua which consists of 8 districts and 1 city. The city of Sorong is located below the equator, between 131051 'east longitude and 00-54 south latitude. The city of Sorong has an area of $1,105 \mathrm{~km} 2$ with geographic boundaries as follows :

a. The west is bordered by the Dampir Strait, Raja Ampat Regency

b. In the north, it is bordered by Makbon District, Sorong Regency and Sagawin Strait, Raja Ampat Regency

c. In the east, it is bordered by Makbon District, Sorong Regency and

d. In the south, it is bordered by Aimas District and Salawati District, Sorong Regency

Which administratively is divided into 6 districts and 31 sub-districts 2011 data on the condition of health workers in the city of Sorong for labor84 Doctors and 168 Paramedics (nurses, pharmacists, midwives, nutritionists, and others).Sorong City Health Facilities and Infrastructure for Government Hospitals 1 and Private Hospitals 5, Puskesmas 6, Puskesmas Assist 29, and Medical Centers 5.1

Univariate Analysis: Univariate analysis is analyzing the data to be tested, namely each independent variable and dependent variable then distributed into a frequency distribution table. The specific data are as follows:

1. Frequency distribution of respondents based on gender (table 4.1). Based on these data, it is known that of the 54 respondents the most were male, namely 35 people $(64.8 \%)$ while women were 19 people (35.2\%).

2. Frequency distribution based on the age of the respondents (table 4.2).

Based on table 4.2, it can be seen that the frequency distribution of respondents is known that of the 54 respondents, the maximum age was 10-14 years, namely 34 people $(63.0 \%)$, while the ages of 5-9 years were 20 people $(37.0 \%)$.

3. Distribution of respondents based on the level of education of parents (table 4.3). 
Based on table 4.3, it can be seen that the frequency distribution of respondents based on the education of the parents of 54 respondents is mostly elementary, junior high school, namely 35 people $(64.8 \%)$, while SMA, PT is 19 people (35.2\%).

4. Distribution of respondents based on the SocioEconomic Status of People (table 4.4) Based on the economy of the parents of 54 respondents, the most were <UMP Sorong, namely 34 people (63.0\%) while $>$ UMP Sorong was 20 people $(37.0 \%)$.

5. Distribution of respondents based on parents' occupation (table 4.5) Based on the work of parents, it is known that of the 54 respondents, at most $>8$ hours a day, namely 38 people $(70.4 \%)$ while $<8$ hours a day, namely 16 people (29.6\%).

6. Distribution of respondents based on Personal Hygiene (table 4.6) Based on personal hygiene, from 54 respondents the most bad was 38 people (70.4\%) while good ones were 16 people (29.6\%).

7. Distribution of respondents based on household contacts (table 4.7)

Based on table 4.7, it can be seen that the frequency distribution of respondents is known that of the 54 respondents at most there were household contacts, 32 people $(59.3 \%)$ while there were no household contacts, namely 22 people (40.7\%).

8. Distribution of respondents based on the incidence of cases (table 4.8)

Based on table 4.8 , it is known that the frequency distribution of respondents based on the incidence of leprosy from 54 case group respondents is 27 people $(50.0 \%)$ while the control group is 27 people $(50.0 \%)$.

Bivariate analysis: Bivariate analysis was carried out to determine the relationship between each independent and dependent variable to see the relationship between the independent variable and the dependent variable.

1. Sex relationship with the incidence of leprosy in Sorong City, West Papua: Chi-square test results obtained $p$ value $(1,000)>\operatorname{sig}(0.05)$ so that Ho is accepted. This means that it can be known, but because the value of the odds ratio $(\mathrm{OR})=1.176$ $(>1=$ risk), this means that male respondents have 1,176 times the risk of getting leprosy compared to female respondents.

Table 1. Cross tab factors sex with The Incidence of Leprosy

\begin{tabular}{|c|c|c|c|c|c|c|c|c|}
\hline \multirow{2}{*}{ Sex } & \multicolumn{6}{|c|}{ Incidence of Leprosy } & \multirow{2}{*}{ P Value } & \multirow{2}{*}{ OR } \\
\hline & N Case & $\%$ & N Control & $\%$ & N Total & $\%$ & & \\
\hline Man & 18 & 51,4 & 17 & 48,6 & 35 & 100 & \multirow{3}{*}{1,000} & \multirow{3}{*}{1,176} \\
\hline Woman & 9 & 47,4 & 10 & 52,6 & 19 & 100 & & \\
\hline Amount & 27 & 50 & 27 & 50 & 54 & 100 & & \\
\hline
\end{tabular}

2. Relationship between Age and the Incidence of Leprosy in Children: The results of the chi-square test obtained $p$ value $(0.788)>\operatorname{sig}(0.05)$ so that Ho was accepted. This means that it can be seen that there is no relationship between age and the incidence of leprosy. The odds ratio $(\mathrm{OR})=1.375$ $(>1=$ risky), this means that respondents aged 5-9 years have a 1.375 times risk of getting leprosy compared to respondents aged 10-14 years.

Table 2. Cross tab age factors with The Incidence of Leprosy

\begin{tabular}{|c|c|c|c|c|c|c|c|c|}
\hline \multirow{2}{*}{ Age (Year) } & \multicolumn{6}{|c|}{ Incidence of Leprosy } & \multirow{2}{*}{ P Value } & \multirow{2}{*}{ OR } \\
\hline & N Case & $\%$ & N Control & $\%$ & N Total & $\%$ & & \\
\hline $5-9$ & 11 & 55,0 & 9 & 45,0 & 20 & 100 & \multirow{3}{*}{0,778} & \multirow{3}{*}{1,37} \\
\hline $10-14$ & 16 & 47,1 & 18 & 52,9 & 34 & 100 & & \\
\hline Amount & 27 & 50 & 27 & 50 & 54 & 100 & & \\
\hline
\end{tabular}


3. The relationship between the socioeconomic level of parents and the incidence of leprosy: Chi-square test results obtained $\mathrm{p}$ value $(0.000)$ $<\operatorname{sig}(0.05)$ so that Ho is rejected. This means that it can be seen that there is a relationship between the economy of the parents and the incidence of leprosy.
The odds ratio $(\mathrm{OR})=13.600(>1=$ risky $)$, this means that respondents with the economic status of the parents $<$ UMP Sorong have a risk of 13.600 times for getting leprosy compared to respondents with the economic status of parents $\geq$ UMP Sorong

Table 3. Cross tab socioecomic parents with The Incidence of Leprosy

\begin{tabular}{|c|c|c|c|c|c|c|c|c|}
\hline \multirow{2}{*}{ Parents economy } & \multicolumn{6}{|c|}{ Incidence of Leprosy } & \multirow{2}{*}{ P Value } & \multirow{2}{*}{ OR } \\
\hline & N Case & $\%$ & N Control & $\%$ & N Total & $\%$ & & \\
\hline$<$ UMP Sorong & 24 & 70,6 & 10 & 29,4 & 34 & 100 & \multirow{3}{*}{0,000} & \multirow{3}{*}{13,600} \\
\hline$\geq$ UMP Sorong & 3 & 15,0 & 17 & 85,0 & 20 & 100 & & \\
\hline Amount & 27 & 50 & 27 & 50 & 54 & 100 & & \\
\hline
\end{tabular}

4. The relationship between education of the respondents' parents and the incidence of leprosy: Chi-square test results obtained $\mathrm{p}$ value $(0.569)>\operatorname{sig}(0.05)$ so that Ho is accepted. This means that it can be seen that there is no relationship between parental education and the incidence of leprosy. Odd ratio $(\mathrm{OR})=1.633$ ( $>1=$ risky), this means that respondents with elementary, junior high school parents' education have a 1.633 times risk of getting leprosy compared to respondents with high school parent education, PT.

5. The relationship between personal hygiene of respondents and the incidence of leprosy: The results of the chi-square test obtained $\mathrm{p}$ value $(0.136)>\operatorname{sig}(0.05)$ so that Ho was accepted. This means that it can be seen that there is no relationship between personal hygiene and the incidence of leprosy. Odd ratio $(\mathrm{OR})=3.025$ ( $>1=$ risky), this means that respondents with poor personal hygiene have 3.025 times the risk of getting leprosy compared to respondents with good personal hygiene.

6. Home contact relationship with leprosy: Chisquare test results obtained p value $(0.000)<$ sig (0.05) so that Ho is rejected. This means that it can be seen that there is a relationship between contact history and the incidence of leprosy. The odd ratio $(\mathrm{OR})$ value $=35,714(>1=$ risky $)$, this means that respondents with a history of household contacts have a 35,714 times risk of getting leprosy compared to respondents with no history of household contacts.

\section{Discussion}

1. The relationship between sex and the incidence of leprosy: Chi-square test results obtained $p$ value $(1,000)>\operatorname{sig}(0.05)$ so that Ho is accepted. This means that it can be known, but because the value of the odds ratio $(\mathrm{OR})=1.176(>1=$ risk $)$, this means that male respondents have 1,176 times the risk of getting leprosy compared to female respondents.

Sex differences in the incidence of leprosy cannot be ascertained, basically leprosy can affect everyone, but men are more affected than women, with a ratio of 2: 1 , although there are some areas that show more female sufferers ${ }^{8}$. The results of this study are in accordance with the opinion of Marwali Harahap ${ }^{17}$ which states that leprosy can attack everyone. Men are more affected than women with a ratio of $2: 12$

2. The relationship between the age of the respondents and the incidence of leprosy: The results of the chi-square test obtained $\mathrm{p}$ value $(0.788)>\operatorname{sig}(0.05)$ so that Ho was accepted. This means that it can be seen that there is no relationship between age and the incidence of leprosy. The odds ratio $(\mathrm{OR})=1.375(>1=$ risky), this means that respondents aged 5-9 years have a 1.375 times risk of getting leprosy compared to respondents aged 1014 years.

The incidence of a disease is often related to age. Chronic diseases such as leprosy are known to occur at all ages, ranging from infants to old age (3 weeks to 
adults over 70 years). However, most of them are at a young and productive age.

The results of this study are in accordance with the results of research by Maria Christiana ${ }^{18}$ in Jepara Regency which states that there is no relationship between age at risk and the incidence of leprosy.

The relationship between education and leprosy: Chi-square test results obtained $\mathrm{p}$ value $(0.569)>$ sig (0.05) so that Ho is accepted. This means that it can be seen that there is no relationship between parental education and the incidence of leprosy. The odd ratio $(\mathrm{OR})=1.633(>1=$ risky $)$, this means that respondents with primary and junior high school parents have a risk of getting leprosy 1.633 times compared to respondents with high school parent education, PT.

\section{The socio-economic relationship between parents} and the incidence of leprosy: Chi-square test results obtained $\mathrm{p}$ value $(0.000)<\operatorname{sig}(0.05)$ so that Ho is rejected. This means that it can be seen that there is a relationship between the economy of the parents and the incidence of leprosy. Odd ratio (OR) $=13.600(>1=$ risky $)$, this means that respondents with economic status of parents $<$ UMP Sorong have a risk of 13.600 times for getting leprosy compared to respondents with economic status of parents $\geq$ UMP Sorong.

The results of the research in Makassar City, it is known that the majority of leprosy sufferers are from low economic groups. The weak socioeconomic condition can be a factor that worsens the development of leprosy. Economic status is a significant risk factor for the incidence of leprosy. Respondents with low economic status have a 41,889 times greater risk of suffering from leprosy than respondents with high economic status. The results of this study are in line with research in Tegal and Christiana Districts in Jepara, showing that economic status is statistically significant with the incidence of leprosy.

Economic factors also influence the needs of life, including food and health needs. If the need for healthy food is not met, it can weaken the immune system, so that it is easy to catch a disease if it gets infected. A person does not take advantage of existing health services, perhaps because there is not enough money to buy medicine, pay for transport and so on, this is in accordance with the opinion which states that leprosy occurs in someone, not easy so there is no need to be afraid. This depends on several factors, including socioeconomic conditions ${ }^{19-23}$.

4. The relationship between parents' work and leprosy: The results of the chi-square test obtained $p$ value $(0.766)>\operatorname{sig}(0.05)$ so that Ho was accepted. This means that it can be seen that there is no relationship between the work of parents and the incidence of leprosy. Odd ratio $(\mathrm{OR})=0.700(<1$ $=$ protective), this means that the work of parents is not too risky with the incidence of leprosy.

Table 4. Cross tab job parents with The Incidence of Leprosy

\begin{tabular}{|c|c|c|c|c|c|c|c|c|}
\hline \multirow{2}{*}{ Job parents } & \multicolumn{6}{|c|}{ The Incidence of Leprosy } & \multirow{2}{*}{ P Value } & \multirow{2}{*}{ OR } \\
\hline & N Case & $\%$ & N Control & $\%$ & N Total & $\%$ & & \\
\hline$\geq 8$ houres a day & 18 & 47,4 & 20 & 52,6 & 38 & 100 & \multirow{3}{*}{0,766} & \multirow{3}{*}{0,700} \\
\hline$<8$ hourse a day & 9 & 56,2 & 7 & 43,8 & 16 & 100 & & \\
\hline Amount & 27 & 50 & 27 & 50 & 54 & 100 & & \\
\hline
\end{tabular}

The statistical test shows that there is a relationship between the type of work and the incidence of leprosy.

This is in line with the research which states that patients with heavy work $(66.7 \%)$ are more vulnerable than patients with light work (33.8\%). Work can be used to analyze any possible risk of developing disease.

5. The relationship between personal hygiene and the incidence of leprosy: The results of the chi- square test obtained $\mathrm{p}$ value $(0.136)>\operatorname{sig}(0.05)$ so that Ho was accepted. This means that it can be seen that there is no relationship between personal hygiene and the incidence of leprosy. Odd ratio (OR) $=3.025(>1=$ risky), this means that respondents with bad personal hygiene have 3.025 times the risk of getting leprosy compared to respondents with good personal hygiene. 
Table 5. Cross tab personal hygiene with The Incidence of Leprosy

\begin{tabular}{|l|c|c|c|c|c|c|c|c|}
\hline \multirow{2}{*}{ Personal hygiene } & \multicolumn{6}{|c|}{ The Incidence of Leprosy } & \multirow{2}{*}{ P Value } & \multirow{2}{*}{ OR } \\
\cline { 2 - 8 } & N Case & $\mathbf{\%}$ & N Control & $\mathbf{\%}$ & N Total & \% & & \\
\hline Well & 22 & 57,9 & 16 & 42,1 & 38 & 100 & & \multirow{2}{*}{3,025} \\
\hline Bad & 5 & 31,2 & 11 & 68,8 & 16 & 100 & \\
\cline { 1 - 8 } Amount & 27 & 50 & 27 & 50 & 54 & 100 & & \\
\hline
\end{tabular}

The results of research by Indriani, et al. in the work area of the Kunduran Health Center, Blora, show that there is a relationship between personal hygiene and the incidence of leprosy. It is concluded that respondents who have poor personal hygiene are not necessarily a risk factor for leprosy. Respondents who had bad personal hygiene had a 5,333 times greater risk of getting leprosy than respondents who had good personal hygiene. This shows personal hygiene risk factors associated with leprosy. The results of the research by NisaAmira, et al. show that there is a relationship between body and hair hygiene and the incidence of leprosy in children in Pasuruan in 2014-2015.
6. Home contact relationship with leprosy: Chisquare test results obtained $\mathrm{p}$ value $(0.000)<\mathrm{sig}$ $(0.05)$ so that Ho is rejected. This means that it can be seen that there is a relationship between contact history and the incidence of leprosy. The odd ratio $(\mathrm{OR})$ value $=35,714(>1=$ risky $)$, this means that respondents with a history of household contacts have a 35,714 times risk of getting leprosy compared to respondents with no history of household contacts.

Table 6. Cross tab house contact with The Incidence of Leprosy

\begin{tabular}{|c|c|c|c|c|c|c|c|c|}
\hline \multirow{2}{*}{ House Contact } & \multicolumn{6}{|c|}{ The Incidence of Leprosy } & \multirow{2}{*}{ P Value } & \multirow{2}{*}{ OR } \\
\hline & N Case & $\%$ & N Control & $\%$ & N Total & $\%$ & & \\
\hline Yes & 25 & 78,1 & 7 & 21,9 & 32 & 100 & \multirow{3}{*}{0,000} & \multirow{3}{*}{35,714} \\
\hline No & 2 & 9,1 & 20 & 90,9 & 22 & 100 & & \\
\hline Amount & 27 & 50 & 27 & 50 & 54 & 100 & & \\
\hline
\end{tabular}

The risk of people with a history of household contacts for contracting leprosy is 15,127 times greater than those with no history of household contacts and this is significant. Contact history is a history of a person who has had contact with a person with leprosy, either at home or not at home. The source of leprosy transmission is whole leprosy originating from leprosy sufferers, so leprosy transmission is easier if there is direct contact with leprosy sufferers ${ }^{13}$.

Based on the results of the statistical test, the OR obtained was 15,127 at 95\% CI 4,572 - 50,056, meaning that the risk of people with a history of household contacts to contract leprosy was 15,127 times greater than those with no history of household contacts and was significant.

\section{Research Limitations:}

\section{Limitations in this study include:}

1. Researchers only use 1: 1 small control due to limited costs, time, and energy in data collection

2. Some respondents can only be met at certain hours, so the researcher adjusts the visiting time

Weaknesses of Research: In the variable length of contact, only research was conducted on the respondent's family member who was diagnosed with leprosy. This does not rule out the possibility that the neighbors around the respondents who are also diagnosed with leprosy, especially the multibacillary type who have not received treatment, can become a source of disease transmission. 
a. There were some respondents who were embarrassed when they met the officers because this disease was still perceived in the community as a curse disease so that an emotional approach was needed.

\section{Conclusion}

Based on data analysis from the results of research that has been done in Sorong City, it can be concluded that

1. Parents' socio-economic factors and a history of household contact are risk factors associated with the incidence of leprosy in children aged 5-14 years in the city of Sorong, West Papua Province.

2. Factors of gender, age, education of respondents, personal hyphenation, work of parents, are not risk factors associated with the incidence of leprosy in children aged 5-14 years in the city of Sorong, West Papua Province.

\section{Suggestion:}

1. Based on the results of this study, there are several suggestions that researchers can convey, namely: Sorong City Health Office In preventing the occurrence of leprosy both in Sorong City, it is hoped that there will be good cooperation between health agencies, especially in increasing the efforts of the Leprosy Eradication Program.

2. The Community: The results of this study are expected to be used as knowledge about the risk factors for the incidence of leprosy so that people are more aware of the risk factors for the disease, so that it is hoped that they can follow up and participate in efforts to prevent and control leprosy.

3. To further researchers: This research still has many shortcomings, it is hoped that further researchers should add research variables, such as health services, attitudes.

Ethical Clearance: Taken from Poltekkes Kemenkes Sorong ethical committee

Source of Funding: Poltekkes Kemenkes Sorong

Conflict of Interest: Nil

\section{References}

1. MOH RI, Epidemiology and Programs. 2005.

2. Ministry of Health, Republic of Indonesia, Handbook of Leprosy Eradication. Prints XV,
Jakarta: Dirjen PPM and PL. 2006

3. Sasakawa Memorial Health Foundation, Atlas of Leprosy, 2004; 1-3.

4. Ministry of Health RI. Indonesia Health Profile 2010. Jakarta: Indonesian Ministry of Health; 2011.

5. Amirudin, MD. Leprosy, A Clinical Approach. Makassar: Brilliant International; 2012.

6. MOH RI, National Guidebook for Leprosy Eradication, 17th Edition, Jakarta: Depkes RI. 2005.

7. MOH RI, National Action Plan for Leprosy Control. 2007.

8. Amiruddin Dali, Leprosy, a Clinical Approach. Brilliant International Sidoarjo. 2012.

9. MOH RI, Indonesia's 2015 Health Profile. 2016.

10. MOH RI, Indonesia Health Profile 2014.

11. Depkes RI, National Leprosy Guidebook for the implementation of leprosy eradication in low endemic areas. Edition 18. Jakarta.2006.

12. Silvia Indriani, Factors Associated with the Incidence of Leprosy. UNNES Semarang. 2014.

13. B. K. Mandal, Infectious Diseases, Translation by Jualita Surapsi. Jakarta: Erlangga. 2006,

14. Sugiono. Administrative Research Method R \& D method. Alfabeta Bandung, 2012

15. Riduwan. Research Variables. Alfabeta Bandung, 2007.

16. Notoatmodjo S. Health Research Methodology. Rineka Cipta Jakarta, 2010.

17. Marwali Harahap, Dermatology, Jakarta: Hippocrates. 2000.

18. Maria Christiana, Risk Factor Analysis of Leprosy (Case Study at Leprosy Hospital Donorejo Jepara) 2008. Thesis: Semarang State University.

19. Mallongi, A., Indra, R., Arief, M.U., Fais Satrianegara, M., Environmental pollution and health problems due to forest fires with $\mathrm{CO}_{2}$ parameters., Medico-Legal Update Volume 20, Issue 3, July-September 2020, Pages 888-892.

20. Mallongi, A., Puspitasari, A., Ikhtiar, M.,Arman, Arsunan, A.A., Analysis of risk on the incidence of scabies Personal Hygiene in Boarding School Darul Arqam Gombara Makassar., Indian Journal of Public Health Research and Development., Volume 9, Issue 4, April 2018, Pages 227-231

21. M N Massi, S Wahyuni, H Halik, Anita, I Yusuf, 
F J Leong, T Dick, S Phyu ., Drug resistance among tuberculosis patients attending diagnostic and treatment centres in Makassar, Indonesia., Int J Tuberc Lung Dis. 2011 Apr;15(4):489-95. doi: 10.5588/ijtld.09.0730.

22. Masriadi, Azis, R., Sumantri, E., Mallongi, A., Effectiveness of non pharmacologic therapy through surveillance approach to blood pressure degradation in primary hypertension patients, Indonesia., Indian Journal of Public Health
Research and Development. Volume 9, Issue 4, April 2018, Pages 249-255

23. Posmaningsih, D.A., Aryasih, G.A.M., Hadi, M.C., Marwati, N.M., Mallongi, A. The influence of media booklet in behavior change of waste management in elementary school students, South Denpasar, Bali., Indian Journal of Public Health Research and Development. Volume 9, Issue 8, August 2018, Pages 1506-1511 